\title{
SCHOOL BULLYING
}

Peter K. Smith

University of London, London, United Kingdom

There is some consensus that bullying is aggressive behaviour which intentionally hurts or harms another person; together with repetition - it happens more than once; and a power imbalance such that it is difficult for the victim to defend him- or herself (Olweus, 1999). A succinct definition is the 'systematic abuse of power' (Smith \& Sharp, 1994). It can occur in many contexts, in childhood and adult life (Monks et al., 2009). However, the earliest sustained work, and the largest volume of work, has concerned school bullying. Bullying can be carried out by a group, or by one stronger individual; although usually considered in the context of pupil-pupil relationships, both teacher-pupil and pupil-teacher bullying may occur. Besides physical bullying - the larger child hitting and beating up a smaller one and verbal bullying - nasty forms of teasing and verbal abuse - there can be indirect and relational bullying. Indirect bullying refers to some kind of social manipulation using others as a means of attack instead of attacking oneself, or otherwise manipulating the social network of the class; and relational bullying to inflicting harm on peers in ways that damage peer relationships; these overlapping concepts cover spreading nasty rumours, and social exclusion. More recently cyberbullying has emerged as a major topic.

Research on school bullying can be thought of as having gone through four waves (Smith, 2012).

\section{First wave: origins 1970s - 1988}

The systematic study of bullying in schools can be dated from the 1970s, mainly in Scandinavia. In 1973 Olweus published Forskning om skolmobbning, translated into English in 1978 Aggression in Schools: Bullies and Whipping Boys. Here, bullying or "mobbing" was defined in terms of physical and verbal behaviours, although Olweus explicitly rejected the "mobbing" label (which implies group bullying), since much bullying appeared to be by one person. Through the 1980s, Olweus developed a self-report questionnaire to assess bullying, an important tool in subsequent work. Also, in parallel with the first Norwegian National Anti-Bullying campaign in 1983, he developed a school-based intervention program. His evaluation of the original version of the Olweus Bullying Prevention Program (1983-1985), with reports of reductions in bullying of around $50 \%$, encouraged researchers and inspired the next wave of research. 


\section{Second wave: establishing a research program 1989 - mid-1990s}

From around 1989, books and journal articles started to appear; and surveys in other countries beyond Scandinavia were beginning to be carried out. Besides self-report surveys, some studies started to use peer nominations methodology. Also, some intervention campaigns took place in other countries, partly inspired by the Norwegian campaign.

An important change in this period was a broadening of researcher's definition of bullying, to include indirect and relational bullying (such as rumour spreading, social exclusion); this followed the similar broadening of understanding of "aggression", following the work of Bjorkqvist and colleagues in Finland, and Crick and colleagues in the USA. Also, work on bullying was becoming more international. Contacts were taking place with researchers in North America, and towards the end of this period, with researchers in Japan. In fact, studies on ijime (the term closest to bullying) dated back at least to the 1980s, but this separate research tradition only made substantial contact with the western research tradition following a Monbusho/UNESCO study in the later 1990s (see Smith et al., 1999).

\section{Third wave: an established international research program mid-1990s - 2004}

During this period, research on "traditional" bullying became an important international research program. Many more publications appeared, and research on bullying featured substantially in European and international conferences. Surveys, and interventions, took place in many countries (see 21 country reports in Smith et al., 1999; and 11 country reports on interventions in Smith, Pepler and Rigby, 2004). A notable methodological step was the introduction of participant roles in bullying, from Salmivalli's work in Finland (Salmivalli et al., 1996). Researchers in the USA substantially developed research on victimization and bullying during this period (Espelage \& Swearer, 2004), and important work was also being undertaken in Australia and New Zealand (Rigby, 2002).

\section{Fourth wave: cyberbullying 2004-}

Over the last decade, cyberbullying has become a significant aspect to be taken account of (Tokunaga, 2010; Smith, 2012). This started off as text message and email bullying, which increased through the mid-2000s (Rivers \& Noret, 2010); but since then the development of smart phones, and greatly increased use social networking sites, have offered many new tools for those wishing to hurt others. Broadly speaking, cyberbullying now takes up an appreciable fraction of total bullying in young people (around one-third). However work on "traditional" or offline bullying has continued to develop (Jimerson, Swearer \& Espelage, 2010). 


\section{Cyberbullying}

Compared to traditional bullying, cyberbullying is much more likely to be perpetrated and experienced outside of school; but is still often between class- or school-mates. Cyberbullying differs from traditional bullying in a variety of ways. Smith (2012) described seven features: (1) it depends on some degree of technological expertise; (2) it is primarily indirect rather than face-to-face, and thus may be anonymous; (3) relatedly, the perpetrator does not usually see the victim's reaction, at least in the short term; (4) the variety of bystander roles in cyberbullying is more complex than in most traditional bullying (the bystander may be with the perpetrator when an act is sent or posted; with the victim when it is received; or with neither, when receiving the message or visiting the relevant Internet site); (5) one motive for traditional bullying is thought to be the status gained by showing (abusive) power over others, in front of witnesses, but the perpetrator will often lack this in cyberbullying; (6) the breadth of the potential audience is increased, as cyberbullying can reach particularly large audiences in a peer group compared with the small groups that are the usual audience in traditional bullying; (7) it is difficult to escape from cyberbullying (there is "no safe haven"), as the victim may be sent messages to their mobile or computer, or access nasty website comments, wherever they are.

By extending the definition from traditional bullying, cyberbullying has been defined as "an aggressive act or behaviour that is carried out using electronic means by a group or an individual repeatedly and over time against a victim who cannot easily defend him or herself" (Smith et al., 2008). However the criteria of repetition, and power imbalance, while relatively clear for traditional bullying, have more difficulties in application to cyberbullying.

First, the idea of repetition within cyberbullying is not as straightforward; one cyberbullying act may readily "snowball" out of the initial control of the bully, due to the technology used. An example is a picture that is sent (or uploaded onto the Internet), that at a later stage is distributed by other people (not the initial perpetrator). Thus a single act by one perpetrator may be repeated many times by others, and experienced many times by the victim. If the repetition is not carried out by the perpetrator, is this still cyberbullying?

The second definitional issue is that of power imbalance. In traditional bullying this might refer to physical or psychological weakness, or it might refer to numbers of aggressors, or popularity/rejection in a peer group context. Such forms of power imbalance within the cyberbullying context are not so clear. Vandebosch and Van Cleemput (2008) argued that a greater knowledge of ICT's may contribute to a power imbalance; they found that pupils with more advanced Internet skills were more likely to have experience with deviant Internet and mobile phone activities. Ybarra and Mitchell (2004) found that cyberbullies do rate themselves as Internet experts to a higher degree compared to those who do not cyberbully others. However, in much of the text message and website bullying experienced by pupils of school age, technological skill is arguably a minor factor. Vandebosch and Van Cleemput (2008) also argued that anonymity can contribute to a power 
imbalance. Often the victim does not know who the person bullying him/her is. It is more difficult to respond effectively if you do not know the identity of the perpetrator. Conversely, if a victim does know the perpetrator, then the more conventional criteria of physical/psychological strength and peer group popularity may come back into play (i.e., a victim may be fearful of retaliating against a popular and stronger pupil who may take further revenge offline).

In summary, defining cyberbullying may not be as clear cut as defining traditional bullying, due to difficulties in the criteria of repetition and power imbalance. These issues, and the extent to which cyberbullying can usefully be distinguished from a broader concept of cyber aggression or cyber victimization, are being debated.

\section{Bias or identity-based bullying}

The terms bias bullying, identity-based bullying or prejudice driven bullying refer to bullying on the basis of group rather than individual characteristics, and include racial harassment, faith-based bullying, sexual harassment, and homophobic bullying. Racist bullying is a worrying feature in some schools, although the extent varies between cultures (Sawyer, Bradshaw \& O'Brennan, 2008). There has been considerable research on homophobic bullying (Rivers, 2011). In secondary schools, children may be teased about their sexual orientation, and even physically assaulted or ridiculed about this by other pupils or teachers. In Great Britain, a Stonewall report (Stonewall, 2007) found that $65 \%$ of lesbian/gay/bisexual (LGB) students reported homophobic victimisation; this was most frequent from boys in the same year group c. $80 \%$ of cases) but not infrequently from girls (c. 50\%). Explicit school rules regarding the issue was associated with lower incidence. In the US, Birkett, Espelage, and Koenig (2009) found that positive school climate can lessen negative outcomes for LGB students.

Another risk factor is having a disability or special educational needs. Children with special needs are two to three times more at risk of being bullied; they are also more at risk of taking part in bullying others (Mishna, 2003). They may have particular characteristics which make them an obvious "target"; in mainstream settings are less well integrated socially and lack the protection against bullying which friendship gives; and, those with behavioural problems may act out in an aggressive way and become "provocative victims". Adolescents with autism spectrum disorders have been found to be at higher victimisation risk, especially when they misinterpret social situations (Roekel, Scholte \& Didden, 2009).

\section{Measurement of bullying}

Large-scale surveys have used questionnaires. The Olweus anonymous self-report questionnaire is the most widely used internationally; it incorporates a standard definition of bullying (Solberg \& Olweus, 2003). Questionnaires have obvious 
advantages in terms of getting information from many informants, quickly and easily. Another well-used methodology is nominations; here, an informant is asked to nominate self or others (e.g. classmates) for involvement in roles such as bully, or victim. A development of this technique allows differentiation of participant roles such as ringleader bully, follower, reinforcer, outsider and defender, as well as victim (Salmivalli et al., 1996); and more recently, asking for who is involved in dyadic relationships in all the main participant roles (Huitsing \& Veenstra, 2012).

Many other methods can provide useful information. These include nominations; interviews and focus groups; diaries, blogs, and drawings; and observations. The informant is often the pupil him- or herself; or a peer - usually someone in the same class, or year group, at school. Self-reports by pupils have been widely used in questionnaires, and pupil reports in peer nomination procedures. The informant can also be an adult at school - usually the class teacher, or perhaps a pastoral care teacher, school nurse or counsellor; and a family member - usually a parent or carer, or perhaps a sibling or other relative. Adult (teacher and parent) reports might have limited value for pupil-pupil bullying, as adults are often only aware of a fraction of what is going on in the peer group.

\section{Prevalence of bullying}

The actual prevalence figures reported in surveys vary very greatly. Considering questionnaire surveys, prevalence rates will be influenced by: what time span is being asked about (e.g. last month, last term, last year, ever at school); what frequency is regarded as bullying (e.g. once/twice a term; once a month, once a week or more); what definition is used (e.g. whether it includes indirect as well as direct forms, and cyberbullying). All these issues make it often difficult to compare across studies; it also means that absolute incidence figures are rather meaningless, in isolation.

Cook et al. (2010) examined quantitative studies of school bullying published from 1999 to 2006. A search revealed 82 studies that met criteria for a meta-analysis. Of these, 45 were in Europe, 21 in the United States, and 16 in other locations. The majority, 61 studies, used self-report data, 13 peer report, and 8 teacher or parent report. The authors calculated average prevalence rates of around $20 \%$ for bullies, $23 \%$ for victims, and $8 \%$ for bully/victims. There was a high variability in figures across studies, but overall these are quite high figures; this is probably because bullying that only happened "once or twice" in a time referent period was included in a number of studies. Peer nomination methods produced lower bully and victim rates than either self or teacher/parent report (but no difference for bully/victim rates).

Two large-scale sources of prevalence data, gathered systematically across countries, come from the World Health Organisation surveys on Health Behaviour in School-aged Children (HBSC); and the EU Kids Online project.

The HBSC surveys collect data from 11-, 13- and 15- years olds from nationally representative samples, every four years, starting in 1993/1994; there is a minimum of 1,500 respondents per year group, in each participating country. These are 
classroom-based, anonymous self-report questionnaire surveys. The reports on bullying are based on a single victim item and a single bully item, adapted from the Olweus questionnaire, which asks about experiences over the past couple of months, with five response options. Victim or bully rates were calculated from, "at least two or three times in the past couple of months" or more (so, ignoring "it only happened once or twice").

Craig et al. (2009) provide findings from the 2005/2006 survey. This data set is from 40 countries, mostly European, but also including the United States, Canada, Russian Federation, and Ukraine. The rates for bullying others average out at $10.7 \%$, and for being bullied (victims) at $12.6 \%$, with $3.6 \%$ scoring as bully/victims. Currie et al. (2012) provide data from the 2009/2010 HBSC survey. This data set is from 38 countries, again mostly European, but also including the United States, Canada, Russian Federation, Armenia and Ukraine. The rates for bullying others average out at $10.3 \%$, and for being bullied (victims) at $11.3 \%$ (there was no separate category for bully/victims). It can be seen that there is a slight decrease in figures between the two surveys. It is also noticeable that these figures are less than half the level from the Cook et al. (2010) review.

Livingstone, Haddon, Görzig and Ólafsson (2011) report findings on traditional bullying and cyberbullying from 25 European countries, from the EU Kids Online survey on Internet use, risks and safety, carried out in spring/summer 2010. The samples were based on random stratified sampling of some 1000 children, aged 9 to 16 years, in each country, with a total sample of 25,142. Self-report survey questionnaires were given face-to-face. A section on bullying explained that this could be face-to-face; or by mobile phone calls or texts; or on the Internet. Then the child or young person was asked whether someone had acted in this hurtful or nasty way to them in the past 12 months, for these three types of activities. Following that, they were asked if they themselves had acted in a hurtful or nasty way to others in the last year. Responses were scored as more than once a week, once or twice a month, less often than that, or never.

Across the European countries, $19 \%$ of 9-16 year olds said that something nasty had happened to them in the past 12 months. However only $5 \%$ said this had happened more than once a week, and another $4 \%$ once or twice a month, with $10 \%$ responding that it was less often. Victim rates were slightly higher in girls, and increased slightly with age. Face-to-face or offline bullying experiences were most frequent at $13 \%$, on the Internet by $6 \%$ (this was mostly on a social networking site or by instant messaging), and by mobile phone by $3 \%$.

Perpetrator or bullying rates averaged $12 \%$ across the whole sample. Only $2 \%$ said this had happened more than once a week, and another $3 \%$ once or twice a month, with $7 \%$ responding that it was less often. There was little gender difference (boys slightly higher at $3 \%$ in the more than once a week category), and bully rates increased somewhat with age. Face-to-face or offline bullying of others was most frequent at $10 \%$, on the Internet by $3 \%$ (this was mostly on a social networking site or by instant messaging), and by mobile phone by $2 \%$.

If one disregards experiences that were less frequent than once or twice a month, then bully prevalence is $5 \%$ and victim prevalence is $9 \%$. This is lower than 
the HBSC findings with a corresponding frequency cutoff, and much lower than the figures from the Cook et al. meta-analysis. The HBSC figures are about $10 \%$ and $11 \%$ respectively, so the main discrepancy is the lower prevalence of bullying others in the EU Kids Online findings. This is unexplained, although one possible explanation could be a greater unwillingness to admit to bullying others in a face-to-face interview compared to an anonymous class-based questionnaire.

\section{Changes in prevalence rates over time}

The two HBSC surveys above show some decrease in bully and victim prevalence rates over time. This appears to be a general trend. Rigby and Smith (2011) reported on various sources of data over the period 1990 to 2009, and concluded that a modest but significant decrease in bullying has been reported in many countries. However, there are some indications that cyber bullying, as opposed to traditional bullying, has increased, at least during some of this period.

\section{Age and gender trends in bullying}

Questionnaire surveys generally show that self-reports of being bullied decline rather steadily through adolescence; self-reports of bullying others do not show this decline (Smith, Madsen \& Moody, 1999). There tends to be some shift with age away from physical bullying and toward indirect and relational bullying. Cyberbullying has a somewhat later age peak, at mid-adolescence, than is found for traditional bullying (Eslea \& Rees, 2001; Tokunaga, 2010).

In traditional bullying, boys are more numerous in the bully category, but the sexes are more equal in the victim category. Boys practice/experience more physical bullying, girls more indirect and relational bullying. Girls' bullying (compared to boys') is more bound up with friendships, feuds and exclusion (Besag, 2006). In cyberbullying, gender differences vary considerably between studies, but relatively, girls may be more involved in cyberbullying and victimisation.

\section{Risk factors in victimisation}

Some risk factors are at the individual level, including genetic factors. In England and Wales the Environmental Risk (E-Risk) Study of over 1000 twin pairs (Ball et al., 2008) found strong genetic influence on children's victimisation status at 9-10 years (MZ [identical] twins had more similar victimisation experiences than DZ twins), and also on bullying behaviour. These genetic factors may operate through various mechanisms including personality disposition, emotion regulation, or social cognition, many identified as individual risk factors in bullying (Farrington \& Baldry, 2010). For example boys who bully have been found to have low affective empathy (sharing others' emotions), although not low cognitive empathy (understanding 
others emotions) (Jolliffe \& Farrington, 2011). In secondary school pupils, moral disengagement, together with expectations of positive outcomes from harmful behaviour, have been found to facilitate both traditional and cyber aggression to peers (Pornari \& Wood, 2009). Although some bullying children may lack social skills, ringleader bullies especially may have good "theory of mind" abilities (understanding of others' mental states) and be skilled social manipulators (Sutton, Smith \& Swettenham, 1999).

In terms of the school peer group, risk factors comprise having few friends, especially friends who can be trusted or who are not themselves of low status; and sociometric rejection (dislike by peers). One hypothesis is that some children who bully are driven by a desire for dominant status in the peer group (Salmivalli, 2010). This highlights the importance of bystanders, with evidence that children with both high empathy and high peer group status, can be the most effective defenders (Nickerson, Mele \& Princiotta, 2008; Caravita, DiBlasio \& Salmivalli, 2009). In-group attitudes within the class or peer group may be influential (Nesdale et al., 2008), and can lead to ostracism of those perceived as different (Dixon, 2007), but there is little evidence for the scapegoating theory (since many classes have no victims, and many have several) (Mahdavi \& Smith, 2007).

In terms of family background factors, there is some evidence that victims may come from over-protective or enmeshed families. Children who bully others may come from families lacking warmth, in which violence is common, and discipline inconsistent. Children who are both bullies and victims, or are aggressive victims, may come from particularly troubled or abusive families (Nickerson, Mele \& Osborne-Oliver, 2010).

The E-Risk study found that school factors were mainly associated with victim risk, family factors with bully risk, and neighbourhood factors with risk of bully/victim status (Bowes et al., 2009); and that maternal and sibling warmth and positive home atmosphere contribute to resilience in coping with victimisation (this twin study demonstrating that this is an environmental, not genetic, effect) (Bowes et al., 2010). School factors may operate through school climate, school policies and anti-bullying strategies; with some research highlighting the role of pupil relationships with teachers (Troop-Gordon \& Quenelle, 2010).

\section{Consequences of involvement in bullying}

A meta-analysis of 11 studies found that between 7 and 16 years, bullies, bully-victims, and victims, all had significantly higher risk of psychosomatic problems compared to uninvolved peers (Gini \& Pozzoli, 2009). Another meta-analysis (Ttofi et al., 2011) found that victimization was a significant risk factor for later depression, even after controlling for up to 20 other risk factors. Rothon et al. (2011) found a significant association of victimisation with poorer academic achievement. A narrative review confirms that being the victim of bullying contributes independently to children's mental health problems, and can have long-lasting effects (Arseneault, Bowes \& Shakoor, 2010). A longitudinal analysis of in England found that being a victim of chronic or 
severe bullying at 8 or 10 years was associated with substantially greater odds of psychotic symptoms at age 12, even controlling for other prior psychopathology, family adversity, and child's IQ (Schreier et al., 2009). Suicidal outcomes can be the most tragic outcome (Kim \& Leventhal, 2008).

A number of studies show links between persistent bullying at school, and later antisocial behaviour and criminal offending (Farrington, Ttofi, \& Lösel, 2011).

\section{Individual coping strategies}

Pupils adopt a variety of coping strategies when bullied. A substantial proportion of self-reported victims say that they have not told a teacher, or someone at home, about the bullying. A consistent finding is that rates of telling a teacher are less in older pupils, and boys (Hunter \& Boyle, 2004). A study of 406 pupils aged 13-16 years found the five most frequent coping strategies were talk to someone, ignore it, stick up for yourself, avoid/stay away from bullies, and make more/different friends (Smith et al., 2004). Over a two year period, those who had stopped being victims more often had talked to someone about it $(67 \%)$ than those who had stayed victims (46\%) or become victims (41\%). Telling teachers can be successful, but clearly needs a consistent and effective response from teaching staff. Telling adults, especially teachers, is particularly low for victims of cyber-bullying.

\section{School-based intervention/prevention}

Actions to reduce bullying in schools can be divided into these into broadly proactive strategies in the school and playground, designed to make bullying less likely to happen; peer support (which is both proactive and reactive); and reactive strategies, as ways of dealing with bullying incidents once they have occurred (Thompson \& Smith, 2012).

Proactive strategies include having a whole school policy on bullying, effective playground supervision, and curriculum work in the classroom. These are well developed for traditional bullying, and resources are being developed tailored for cyberbullying. A European resource, CyberTraining - AResearch-based European Training Manual on Cyberbullying, is available at http://www.cybertraining-project.org.

In peer support systems, selected students are trained to be peer supporters, to deal with interpersonal conflicts, social exclusion and bullying in proactive and non-violent ways. In primary schools, buddies and befrienders generally look out for pupils at breaktimes, who are upset or lonely. Playleaders or playground pals lead structured games activities. In the secondary sector, peer supporters, usually from older year groups, can be used to support younger students at transition and can also provide one to one mentoring/counselling for bullied students in a designated room. Crucial issues include the selection and training of peer supporters; the gender balance in recruitment (there are often more girl than boy volunteers, particularly in the 
secondary sector); adequate and continuing supervision by an accessible member of staff; effective promotion of the scheme; and sufficient take-up that peer supporters feel positive in their role. In a review, Cowie and Smith (2010) argued that schools using well-managed peer support schemes are seen as being more caring and concerned about pupil well-being, and the schemes are known and supported by pupils and staff; in addition, the peer supporters themselves generally benefit from the experience. There is evidence from individual cases that some pupils, who use peer support schemes for reasons of being bullied, report being helped. However most of the relevant studies do not report significant changes in general levels of bullying behaviour as a result of implementing a peer support scheme.

A UK charity, Beatbullying, launched a new form of virtual peer support called CyberMentors in 2009. Students are trained as cybermentors, log on and mentor on demand. Cybermentors can refer mentees on to senior cybermentors and counselors for further support if necessary. This scheme is being extended to other European countries.

Reactive strategies are a response to bullying incidents when they have happened. Reactive strategies range from sanction-based approaches, through restorative practices, to more indirect and non-punitive approaches. Direct sanctions range from verbal reprimands from the head teacher; meetings involving parents or carers; temporary removal from class; withdrawal of privileges and rewards; disciplinary measures such as detentions; punishment such as litter-picking/ school clean-ups; through to temporary or permanent exclusion. Restorative approaches aim to restore good relationships rather than mete out punishment; they include a hierarchy of flexible responses, ranging from informal conversations through to formal facilitated meetings or conferences. The underlying principle is to work to resolve conflict and repair harm. Non-punitive approaches include the Pikas method, and the Support Group Method. These do not hold the perpetrator responsible directly, but aim to change problem behaviours through a mixture of peer pressure to elicit a prosocial response, and self realisation of the harm and suffering caused to the victim. There is continuing controversy over the best balance between these approaches (Rigby, 2010; Thompson \& Smith, 2012).

\section{Evaluations of program interventions}

There are anti-bullying programs available with a structured set of components and sequence of activities. The first was the Norwegian Nationwide campaign against bullying, which was launched through mass publicity in 1983, and involved a survey in schools; resources for teachers (curricular materials and videos) and advice for parents. This was developed by Olweus into the Olweus Bulling Prevention Program (OBPP) (Olweus, 1999; Olweus \& Limber, 2010); this has school-level components, classroom-level components, individual-level components, and community-level component).

An evaluation in the First Bergen Project (1983-85) involved 42 schools. The effect on rates of bullying was dramatic with reported victim rates falling by around 
$50 \%$, for both boys and girls. A second Bergen project (1997-98) involved 14 intervention schools and 16 comparison schools. Bullying decreased by between $21-38 \%$ in intervention schools, with no change or increase in comparison schools. A first Oslo project (2001-2002) in 37 schools showed reductions of some $30-45 \%$ in victimisation and bullying. Olweus and Limber (2010) report findings associated with a New National initiative in Norway, with reductions in the range of 37\%-49\%. The success of the OBPP in Norway is thus substantial and well-replicated. The program has been used outside Norway, for example in Canada, Germany, the Netherlands, and the USA, but with less consistent success (Thompson \& Smith, 2012).

A recent and ongoing program in Finland, the KiVa Koulu program, is innovative in its methods and producing findings on a level with the OBPP in Norway (Kärnä et al., 2011). KiVa includes universal interventions (e. g. via the classroom) and targeted interventions (individual discussions with victims and bullying children, and using prosocial, high-status peers to be defenders). The classroom work includes an anti-bullying virtual learning environment; the KiVa computer game uses simulated characters and episodes learn facts and try out strategies, which can then be applied to everyday life at school. So far evaluations have been encouraging, with reductions of around 34-37\%, with indications that both more disciplinary methods, and non-punitive approaches, can be helpful. Although primarily designed with traditional bullying in mind, evaluations so far show that KiVa is as effective in reducing cyberbullying as it is for a range of traditional forms (Salmivalli, Kärnä, \& Poskiparta, 2011).

\section{Meta-analyses of large-scale interventions}

Ttofi and Farrington (2011) provide a meta-analysis of 44 school-based intervention programmes internationally. They found that on average, these reduced bullying by around $20-23 \%$ and victimisation by around $17-20 \%$; although there is considerable variation in outcomes. They also examined, across programs, which program components were most associated with success. For reducing victim rates, most associated with success were use of videos, disciplinary methods, parent training/meetings, and cooperative group work; but work with peers was associated with a significant increase in victimization. For reducing bullying, most associated with success were parent training/meetings, improved playground supervision, disciplinary methods, school conferences, information for parents, classroom rules, classroom management and teacher training.

The overall conclusion of reductions of around $20 \%$ or more appears a robust finding, and quite encouraging, even if many programs do not reach the success of OBPP in Norway, or KiVa in Finland. The conclusions drawn about individual component effectiveness are an important step forward, but likely to be less robust. Their analysis is limited historically in that the interventions surveyed cover some 25 years, whereas methods of intervention have been and still are being developed and changed. Some of Ttofi and Farrington's analyses (for example, suggesting that work with peers is relatively ineffective; or that disciplinary methods are 
advantageous) depend very much on how terms such as "work with peers" and "disciplinary methods" are interpreted. The importance of different intervention components is still a matter of debate (Smith, Salmivalli \& Cowie, 2012).

The advent of cyberbullying in the last decade poses new challenges for anti-bullying interventions. There is considerable overlap in involvement in traditional forms of bullying and cyberbullying, but some distinctive features of cyberbullying also require other forms of intervention, including education on rights and responsibilities online (Bauman, 2010).

\section{Conclusions}

The need for continuing anti-bullying work, in schools and other places used by children and young people, is obvious from current prevalence rates and the accumulating evidence of the causal influence of victimization on mental health issues and adjustment. Present indications are that bullying is not getting worse. Over the last two decades a range of anti-bullying interventions have become available, and are disseminated and widely employed, in schools in industrialised countries. Reviews suggest that these have some success and are worthwhile in terms of reducing suffering and ultimately enhancing school climate and good citizenship. There is still much to be learnt, particularly about the effectiveness of specific intervention components. Cyberbullying provides new challenges, as being a relatively new form of bullying with its own characteristics and somewhat different modes of effective intervention.

School bullying is an area where research and practice have gone hand in hand, with good evidence that the outcomes have improved pupil well-being and happiness. The continuing synergy between research findings, both national and international, and policy and practice, has promise of building on the modest but significant successes so far, in creating safer environments in which children and young people can live, grow, play and learn.

\section{References}

Arseneault, L., L. Bowes, and S. Shakoor (2010), “Bullying victimization in youths and mental health problems: 'Much ado about nothing'", Psychological Medicine, 40 (5), pp. 717-729.

Ball, H. A., L. Arsenault, A. Taylor, B. Maughan, A. Caspi, and T. E. Moffitt (2008), "Genetic and environmental influences on victims, bullies and bully-victims in childhood", Journal of Child Psychology and Psychiatry, 49, pp. 104-112.

Bauman, S. (2010), Cyberbullying. What Counsellors Need to Know, Alexandria, VA, American Counseling Association (www.counselling.org)

Besag, Valerie E. (2006), Understanding Girls' Friendships, Fights and Feuds. A Practical Approach to Girls' Bullying, Maidenhead, UK, Open University Press.

Birkett, M., D. L. Espelage, and B. Koenig (2009), “LGB and questioning students in 
schools: the moderating effects of homophobic bullying and school climate on negative outcomes", Journal of Youth and Adolescence, 38, pp. 989-1000.

Bowes, L., L. Arsenault, B. Maughan, A. Taylor, A. Caspi, and T. E. Moffitt (2009), "School, neighborhood, and family factors are associated with children's bullying involvement: a nationally representative longitudinal study", Journal of the American Academy of Child and Adolescent Psychiatry, 48, pp. 545-553.

Bowes, L., B. Maughan, A. Caspi, T. E. Moffitt, and L. Arseneault (2010), “Families promote emotional and behavioural resilience to bullying: evidence of an environmental effect", Journal of Child Psychology E Psychiatry, 51, pp. 809-817.

Caravita, S., P. DiBlasio, and C. Salmivalli (2009), “Unique and interactive effects of empathy and social status on involvement in bullying", Social Development, 18, pp. 140-163.

Cook, C. R., K. R. Williams, N. G. Guerra, and T. E. Kim (2010), "Variability in the prevalence of bullying and victimization: a cross-national and methodological analysis", in S. R. Jimerson, S. M. Swearer, and D. L. Espelage (eds.), Handbook of Bullying in Schools. An International Perspective, New York \& London, Routledge, pp. 347-362.

Cowie, H., and P. K. Smith (2010), "Peer support as a means of improving school safety and reducing bullying and violence", in B. Doll, W. Pfohl, and J. Yoon (eds.), Handbook of Youth Prevention Science, New York, Routledge, pp. 177-193.

Craig, W., Y. Harel-Fisch, H. Fogel-Grinvald, S. Dostaler, J. Hetland, B. Simons-Morton, B. Molcho, M. Gaspar de Mato, M. Overpeck, P. Due, W. Pickett, HBSC Violence \& Injuries Prevention Focus Group, and HBSC Bullying Writing Group (2009), “A cross-national profile of bullying and victimization among adolescents in 40 countries", International Journal of Public Health, 54 (Suppl. 2), pp. 216-224.

Currie, C., et al. (eds.) (2012), Social Determinants of Health and Well-Being among Young People. Health Behaviour in School-aged Children (HBSC) Study. International Report From the 2009/23010 Survey, Copenhagen, WHO Regional Office for Europe.

Dixon, R. (2007), “Ostracism: one of the many causes of bullying in groups?", Journal of School Violence, 6, pp. 3-26.

Eslea, M., and J. Rees (2001), "At what age are children most likely to be bullied at school?", Aggressive Behaviour, 27, pp. 419-429.

Espelage, D. L., and S. M. Swearer (eds.) (2004), Bullying in American Schools. A Socio-ecological Perspective on Prevention and Intervention, Mahwah, NJ, and London, Lawrence Erlbaum.

Farrington, D., and A. Baldry (2010), "Individual risk factors for school bullying”, Journal of Aggression, Conflict and Peace Research, 2, pp. 4-16.

Farrington, D. P., M. M. Ttofi, and F. Lösel (2011), “Editorial: school bullying and later criminal offending", Criminal Behaviour and Mental Health, 21, pp. 77-79.

Gini, G., and T. Pozzoli (2009), "Association between bullying and psychosomatic symptoms: a meta-analysis", Pediatrics, 123, pp. 1059-1065.

Huitsing, G., and R. Veenstra (2012), “Bullying in classrooms: participant roles from a social network perspective", Aggressive Behavior, 38, pp. 494-509.

Hunter, S. C., and J. M. E. Boyle (2004), "Appraisal and coping strategy use of victims of school bullying", British Journal of Educational Psychology, 74, pp. 83-107. 
Jimerson, S. R., S. M. Swearer, and D. L. Espelage (eds.) (2010), Handbook of Bullying in Schools. An International Perspective, New York \& London, Routledge.

Jolliffe, D., and D. P. Farrington (2011), "Is low empathy related to bullying after controlling for individual and social background variables?", Journal of Adolescence, 34, pp. 59-71.

Kärnä, A., M. Voeten, T. Little, E. Poskiparta, A. Kaljonen, and C. Salmivalli (2011), "A large scale evaluation of the KiVa antibullying program: grades 4-6", Child Development, 82, pp. 311-330.

Kim, Y.-S., and B. Leventhal (2008), "Bullying and suicide: a review”, International Journal of Adolescent Mental Health, 20, pp. 133-154.

Livingstone, S., L. Haddon, A. Görzig, and K. Ólafsson (2011), Risks and Safety on the Internet. The Perspective of European Children. Full Findings, London, LSE, EU Kids Online.

Mahdavi, J., and P. K. Smith (2007), "Individual risk factors or group dynamics? An investigation of the scapegoat hypothesis of victimisation in school classes", European Journal of Developmental Psychology, 4, pp. 353-371.

Mishna, F. (2003), "Learning disabilities and bullying: double jeopardy", Journal of Learning Disabilities, 36, pp. 336-347.

Monks, C. P., P. K. Smith, P. Naylor, C. Barter, J. L. Ireland, and I. Coyne (2009), “Bullying in different contexts: commonalities, differences and the role of theory", Aggression and Violent Behavior, 14, pp. 146-156.

Nesdale, D., K. Durkin, A. Maass, J. Kiesner, and J. A. Griffiths (2008), “Effects of group norms on children's intentions to bully", Social Development, 17, pp. 889-907.

Nickerson, A. B., D. Mele, and K. M. Osborne-Oliver (2010), “Parent-child relationships and bullying", in S. R. Jimerson, S. M. Swearer, and D. L. Espelage (eds.), Handbook of Bullying in Schools. An International Perspective, New York \& London, Routledge, pp. 187-197.

Nickerson, A. B., D. Mele, and D. Princiotta (2008), "Attachment and empathy as predictors of roles as defenders or outsiders in bullying interactions", Journal of School Psychology, 46, pp. 687-703.

Olweus, D. (1999), “Sweden”, in P. K. Smith, Y. Morita, J. Junger-Tas, D. Olweus, R. Catalano, and P. Slee (eds.) (1999), The Nature of School Bullying. A Cross-National Perspective, London \& New York, Routledge, pp. 7-27.

Olweus, D., and S. Limber (2010), “The Olweus Bullying Prevention Program: implementation and evaluation over two decades", in S. R. Jimerson, S. Swearer, and D. L. Espelage (eds.), Handbook of Bullying in Schools. An International Perspective, New York \& London, Routledge, pp. 377-401.

Pornari, C. D., and J. Wood (2009), "Peer and cyber aggression in secondary school students: the role of moral disengagement, hostile attribution bias, and outcomes expectancies", Aggressive Behavior, 36, pp. 81-94.

Rigby, K. (2002), New Perspectives on Bullying, London \& Philadelphia, Jessica Kingsley.

Rigby, K. (2010), Bullying Interventions in Schools. Six Basic Approaches, Camberwell, ACER.

Rigby, K., and P. K. Smith (2011), "Is school bullying really on the rise?", Social Psychology of Education, 14, pp. 441-455. 
Rivers, I. (2011), Homophobic Bullying. Research and Theoretical Perspectives, Oxford, Oxford University Press.

Rivers, I., and N. Noret (2010), “I h8 u': findings from a five-year study of text and email bullying", British Educational Research Journal, 36, pp. 643-671.

Roekel, E. van, R. H. J. Scholte, and R. Didden (2009), “Bullying among adolescents with autism spectrum disorders: prevalence and perception", Journal of Autism and Developmental Disorders, 40, pp. 63-73.

Rothon, C., J. Head, E. Klineberg, and S. Stansfeld (2011), “Can social support protect bullied adolescents from adverse outcomes? A prospective study on the effects of bullying on academic achievement and mental health of adolescents at secondary schools in East London", Journal of Adolescence, 34, pp. 579-588.

Salmivalli, C. (2010), "Bullying and the peer group: a review”, Aggression and Violent Behavior, 15, pp. 112-120.

Salmivalli, C., A. Kärnä, and E. Poskiparta (2011), “Counteracting bullying in Finland: the KiVA Program and its effects on different forms of being bullied", International Journal of Behavioural Development, 35, pp. 405-411.

Salmivalli, C., K. Lagerspetz, K. Björkqvist, K. Österman, and A. Kaukiainen (1996), "Bullying as a group process: participant roles and their relations to social status within the group", Aggressive Behavior, 22, pp. 1-15.

Sawyer, A. L., C. P. Bradshaw, and L. M. O’Brennan (2008), “Examining ethnic, gender, and developmental differences in the way children report being a victim of 'bullying' on self-report measures', Journal of Adolescent Health, 43, pp. 106-114.

Schreier, A., D. Wolke, K. Thomas, J. Horwood, C. Hollis, D. Gunnell, G. Lewis, A. Thompson, S. Zammit, L. Duffy, G. Salvi, and G. Harrison (2009), "Prospective study of peer victimization in childhood and psychotic symptoms in a nonclinical population at age 12 years", Archives of General Psychiatry, 66, pp. 527-536.

Smith, P. K. (2012), "Cyberbullying and cyber aggression”, in S. R. Jimerson., A. B. Nickerson., M. J. Mayer., and M. J. Furlong (eds.), Handbook of School Violence and School Safety. International Research and Practice, New York, Routledge, pp. 93-103 ( $2^{\text {nd }}$ ed.).

Smith, P. K., K. Madsen, and J. Moody (1999), “What causes the age decline in reports of being bullied at school? Towards a developmental analysis of risks of being bullied", Educational Research, 41, pp. 267-285.

Smith, P. K., J. Mahdavi, M. Carvalho, S. Fisher, N. Russell, and N. Tippett (2008), "Cyberbullying: its nature and impact in secondary school pupils", Journal of Child Psychology \& Psychiatry, 49, pp. 376-385.

Smith, P. K., Y. Morita, J. Junger-Tas, D. Olweus, R. Catalano, and P. Slee (eds.) (1999), The Nature of School Bullying. A Cross-National Perspective, London \& New York, Routledge.

Smith, P. K., D. Pepler, and K. Rigby (eds.) (2004), Bullying in Schools. How Successful Can Interventions $\mathrm{Be}$ ?, Cambridge, Cambridge University Press.

Smith, P. K., C. Salmivalli, and H. Cowie (2012), “Effectiveness of school-based programs to reduce bullying: a commentary", Journal of Experimental Criminology, 8, pp. 433-441.

Smith, P. K., and S. Sharp (eds.) (1994), School Bullying. Insights and Perspectives, London, Routledge. 
Smith, P. K., L. Talamelli, H. Cowie, P. Naylor, and P. Chauhan (2004), “Profiles of non-victims, escaped victims, continuing victims and new victims of school bullying", British Journal of Educational Psychology, 74, pp. 565-581.

Solberg, M. E, and D. Olweus (2003), "Prevalence estimation of school bullying with the Olweus Bully/Victim Questionnaire", Aggressive Behavior, 29, pp. 239-268.

Stonewall (2007), “The school report: the experiences of young gay people in Britain's schools", available at: www.stonewall.org.uk/documents/school_report.pdf

Sutton, J., P. K. Smith, and J. Swettenham (1999), “Bullying and theory of mind: a critique of the 'social skills deficit' view of anti-social behavior", Social Development, 8 , pp. 117-127.

Thompson, F., and P. K. Smith (2012), "Anti-bullying strategies in schools: what is done and what works", British Journal of Educational Psychology, Monograph Series II, 9, pp. 154-173.

Tokunaga, R. S. (2010), "Following you home from school: a critical review and synthesis of research on cyberbullying victimization", Computers in Human Behavior, 26, pp. 277-287.

Troop-Gordon, W., and A. Quenelle (2010), “Children's perceptions of their teacher's responses to student's peer harassment: moderators of victimization-adjustment linkages", Merrill-Palmer Quarterly, 56, pp. 333-360.

Ttofi, M. M., and D. P. Farrington (2011), “Effectiveness of school-based programs to reduce bullying: a systematic and meta-analytic review", Journal of Experimental Criminology, 7, pp. 27-56.

Ttofi, M. M., D. P. Farrington, F. Lösel, and R. Loeber (2011), “Do the victims of school bullies tend to become depressed later in life? A systematic review and meta-analysis of longitudinal studies", Journal of Aggression, Conflict and Peace Research, 3, pp. 63-73.

Vandebosch, H., and K. van Cleemput (2008), “Defining cyberbullying: a qualitative research into the perceptions of youngsters", CyberPsychology \& Behavior, 11, pp. 499-503.

Ybarra, M. L., and K. J. Mitchell (2004), “Online aggressor/targets, aggressors, and targets: a comparison of associated youth characteristics", Journal of Child Psychology and Psychiatry, 45, pp. 1308-1316.

Peter K. Smith. Emeritus Professor at Goldsmiths, University of London, Department of Psychology, Unit for School and Family Studies.

E-mail: p.smith@gold.ac.uk

\section{Resumo/abstract/résumé/resumen}

Bullying escolar

O bullying é definido como um abuso sistemático de poder. O desenvolvimento do programa de pesquisa sobre bullying escolar é delineado em quatro fases. 
É sublinhada a natureza distinta do cyberbullying, e também da identidade baseada no bullying. Discute-se os métodos de medição e os tipos de taxas de prevalência obtidos. Enuncia-se um conjunto de fatores de risco para o envolvimento como agressor/vítima. Descreve-se uma série de intervenções centradas na escola juntamente com a discussão de uma meta-análise dos seus resultados. Em resumo, a investigação e a prática têm andado a par na pesquisa analisada, e tiveram algum sucesso pelo menos em reduzir o que é um problema significativo na vida de muitas crianças.

Palavras-chave bully, vítima, cyber/virtual, lidar/enfrentar, intervenção.

\section{School bullying}

Bullying is defined as a systematic abuse of power; the development of the research program on school bullying is outlined over four phases. The distinctive nature of cyberbullying, and also of identity-based bullying, is outlined. Measurement methods are discussed, and the kinds of prevalence rates obtained. A range of risk factors for involvement as a bully, or victim, are summarized. A range of school-based interventions are described, together with discussion of a meta-analysis of their outcomes. In summary, research and practice have gone hand-in-hand in the research reviewed, and have had some success in at least reducing what is a significant problem in the lives of many children.

$\underline{\text { Keywords }}$ bully, victim, cyber, coping, intervention.

\section{Le harcèlement à l'école}

Le harcèlement est défini comme un abus systématique de pouvoir. Le développement du programme de recherche sur le harcèlement à l'école se décline en quatre phases. La nature distincte du cyber-harcèlement, ainsi que de l'identifié fondée sur le harcèlement, est soulignée. Les méthodes de mesure sont discutées et les types de taux de prévalence obtenus. Un ensemble de facteurs de risque pour devenir un harceleur ou une victime sont énoncés. Une série d'interventions centrées sur l'école sont décrites, avec la discussion d'une méta-analyse des résultats. En résumé, la recherche et la pratique se côtoient dans la recherche analysée, et elles ont du moins contribué à réduire un problème important dans la vie de beaucoup d'enfants.

Mots-clés harceleur, victime, cyber-harcèlement, gérer/affronter, intervention. 


\section{Bullying escolar}

El bullying es definido como un abuso sistemático de poder. El desarrollo del programa de investigación sobre bullying escolar está delineado en cuatro fases. La naturaleza distinta del cyberbullying, y también de la identidad basada en el bullying, son subrayados. Se discuten los métodos de medición y los tipos de tasas de prevalencia obtenidos. Se encuentran resumidos un conjunto de factores de riesgo para la transformación como un agresor, o víctima. Una serie de intervenciones centradas en la escuela son descritas, conjuntamente con la discusión de un meta-análisis de sus resultados. En resumen, la investigación y la práctica van de la mano en la pesquisa analizada, y tuvieron algún éxito por lo menos en reducir lo que es un problema significativo en la vida de muchos niños.

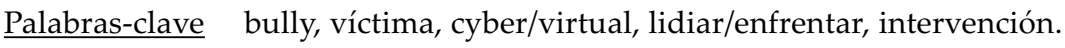

